\title{
SPORTS PERFORMANCE AS A MODERATOR OF THE RELATIONSHIP BETWEEN COPING STRATEGY AND EMOTIONAL INTELLIGENCE
}

\author{
Petar Mitić1, Jasmina Nedeljkovićn , Vladimir Takšić ${ }^{3}$, Goran Sporiš ${ }^{4}$, \\ Nenad Stojiljković ${ }^{1}$, and Lucija Milčić ${ }^{4}$ \\ ${ }^{1}$ Faculty of Sport and Physical Education, University of Niš, Serbia \\ ${ }^{2}$ Faculty of Legal and Business Studies dr Lazar Vrkatić, \\ Department of Psychology, Novi Sad, Serbia \\ ${ }^{3}$ Faculty of Humanities and Social Sciences, University of Rijeka, Croatia \\ ${ }^{4}$ Faculty of Kinesiology, University of Zagreb, Croatia
}

Original scientific article

DOI: $10.26582 / \mathrm{k} .52 .2 .15$

\begin{abstract}
:
The sample consisted of 171 elite and 169 non-elite athletes. linear regression analysis was used to test the prognostic role of emotional competence on stress coping strategies, and hierarchical regression analysis was used to test the moderating role of performance in the relationship between emotional competence and coping strategies. The result shows that EI is related to task-oriented strategies and completely unrelated to emotion-oriented strategies. Sport performance moderates the relationship between managing and regulating emotions and using avoidant coping strategies, in a way that non-elite athletes with higher scores on this EI subfactor are more likely to use distraction-oriented coping.
\end{abstract}

Key words: emotional intelligence, coping, moderation, elite athletes, non-elite athletes

\section{Introduction}

Sports situations are quite frequently stressful, especially when it comes to competitive sports. The sources of stress in a sporting context are numerous such as physical fitness of the athlete, the quality of the opponent, performance pressures and expectations team climate, problems in dealing with other significant people, making a physical or mental mistake, anticipating criticism or reprimands of the coach, watching the opponent cheat, experiencing pain or injury (Anshel \& Kaissidis, 1997; Mellalieu, Hanton, \& Fletcher, 2006; Noblet \& Gifford, 2002). Consequences of stress in a sporting context can easily affect sports performance by the onset of increased anxiety and burn-out syndrome, increased aggression and bullying, decreased self-esteem and enjoyment of sports, and motor performance problems (Burton \& Raedeke, 2008). Confronted with stress, we cope with it. Coping implies everything that a person does, whether on a cognitive or behavioral plane, with the aim of solving the problem and/or reducing the intensity of the psychophysiological response within the stress process (Lazarus \& Folkman, 1984) and this implication has not changed significantly in recent decades. Zotović (2004) considers that coping does not have to be a completed or successful act.
Commencing with the transactional approach, Endler and Parker (1990) argue that there are three dimensions (styles) of coping: task-oriented coping, emotion-oriented coping, and avoidance-oriented coping (social diversion and distraction). In situations that are estimated as being controllable, active (problem-oriented) forms of stress management are more commonly applied (Anshel \& Kaissidis, 1997). Stress coping styles in athletes also reflect a relatively stable and consistent tendency to use specific coping strategies (the choice of strategies reflects the dominant coping style of the athlete), especially as a function of the type of stressor (Anshel, Sutarso \& Jubenville, 2009; Gould, Finch \& Jackson. 1993). The use of problem-oriented coping strategies is positively correlated with a sense of sport enjoyment, while the desire to continue participating in sporting activities is negatively correlated with the use of avoidance-coping strategies (Kim \& Duda, 2003). Distraction-oriented coping showed no significant correlation with athletic achievement (Gaudreau, Nicholls, \& Levy, 2010), and emotional maturity was correlated with task-oriented coping (Nicholls, Levy, \& Perry, 2015).

Coping varies depending on the age and gender of the athlete (Anshel, et al., 2009; Kaiseler, Polman, \& Nicholls 2012; Nicholls \& Polman, 
2007; Reeves, Nicholls \& McKenna, 2009; Sagar, Lavallee, \& Spray, 2009), type of stress (Nicholls, 2007; Nicholls, Holt, Polman, \& Bloomfield., 2006), motivation and perceived social support (Fletcher \& Sarkar, 2012). Elite athletes use several different coping strategies (Cosh, \& Tully, 2015) especially in comparison to non-elite ones (Calmeiro, Tenenbaum, \& Eccles, 2014). In cases of intense cognitive anxiety, athletes use avoidance and emotionoriented coping (Kurimay, Pope-Rhodius, \& Kondric, 2017). Proper use of coping strategies is related to athletes' resilience (Belem, Caruzzo, Nascimento Junior, Vieira, \& Vieira, 2014). Various forms of coping are required for a wide variety of stressors in sports (Kavanagh, Brown, \& Jones, 2017). Coping and emotional intelligence (EI) in sports are also correlated with a decision-making process (Laborde, Dosseville, \& Kinrade, 2014; Vaughan, Laborde, \& McConville, 2019).

Coping can be observed at the intraindividual and team level (Tamminen \& Gaudreau, 2014). Teammates also significantly influence both stress assessment and coping (Kerdijk, Van Der Kamp, \& Polman, 2016). Basically, both stressors and coping are susceptible to social influences (Campo, Mellalieu, Ferrand, Martinent, \& Rosnet, 2012). Athletes seek team support when confronted with different stressors, acknowledge the fact that their teammates' emotions affect them, that they attempt to control their own emotions so as not to disturb teammates, and they also try to control teammates' emotions to enhance team performance (Crocker, Tamminen, \& Gaudreau, 2015). This forms the basis for the study of communal coping (Lyons, Mickelson, Sullivan, \& Coyne, 1998) in sport, but also the logical basis for further correlating of emotional intelligence with various forms of coping in sport. Communal coping has been researched in parents and young athletes (Neely, McHugh, Dunn, \& Holt, 2017) and in team sports (Leprince, D'Arripe-Longueville, \& Doron, 2018).

Emotional intelligence consists of four abilities: (1) the ability to quickly perceive, assess and express emotions, (2) the ability to perceive and generate feelings that facilitate thinking, (3) the ability to understand emotions and knowledge of emotions, and (4) the ability to regulate emotions to improve emotional and intellectual development (Salovey \& Mayer, 1990). The greatest doubt about emotional intelligence is whether it is an ability or a personality trait. This doubt arises, first of all, from the operationalization of the measurement object. Authors who advocate viewing emotional intelligence as a trait, operationalize it through selfassessment questionnaires (like most personality tests), and name it another trait of emotional selfefficacy (Petrides, 2011). Such models are generally characterized by a three- or four-factor structure and establish a low correlation with scores on general (academic) intelligence (Perez, Petrides, \& Furnham, 2005). Takšić $(1998,2002)$ assumes a three-factor structure of emotional intelligence (or emotional competence, as he calls it) comprising the following factors: the ability to perceive and understand emotions, the ability to express and name emotions, and the ability to manage and regulate emotions.

Research supports the correlation between EI and sports performance. Athletes with high emotional intelligence are more likely to use psychological skills and techniques in both training and competition (Lane, Thelwell, Lowther, \& Devonport, 2009), experience pleasant emotions significantly more often than unpleasant ones (Lane \& Wilson, 2011), experience a lower increase of stress as measured by an increase in heart rate (Laborde, Brüll, Weber, \& Anders, 2011), or on the whole, they are more successful (Crombie, Lombard, \& Noakes, 2009; Perlini \& Harvelson, 2006). The EI trait is related to the satisfaction with sports performance (Laborde, Dosseville, Guillén, \& Chávez, 2014) and is equally significant in both individual and team sports (Laborde, Guillén, \& Watson, 2017). Coaches using EI reduce athletes' anxiety (Barlow $\&$ Banks, 2014) and meet their basic needs (Watson \& Kleinert, 2019).

Research findings in other areas of psychology support the thesis that individuals who are more emotionally intelligent cope more effectively with stress by using more adaptive coping strategies (Jordan, Ashkanasy, \& Hartel, 2002; Por, Barriball, Fitzpatrick, \& Roberts, 2011; Salovey, Stroud, Woolery, \& Epel, 2002). The results of certain studies (Gohm, Corser, \& Dalsky, 2005; Matthews, Zeidner, \& Roberts, 2004) indicate that the relationship between emotional intelligence and stress reduction through the use of adaptive strategies is not universal, that is, emotional intelligence can help reduce stress, but not to all people (existence of a moderator variables, such as personality traits). Some authors argue that the relationship between emotional intelligence and coping effectiveness is moderated by mental toughness (Cowden, 2016). It is thought that emotional intelligence can be developed in general (Bagshaw, 2000; Slaski \& Cartwright, 2005) and trough sports as well (Campo, Laborde, \& Mosley, 2016; Szabo \& Urbán, 2014).

The research supporting the correlation between EI and coping in sports, as well as the increasing interest in communal coping, has led to the study. The aim of this study was to examine the moderating role of sports performance in the relationship between emotional intelligence and stress coping strategies. So as to achieve this goal, it was necessary to determine the relationship between emotional intelligence components as a trait and stress coping strategies in elite and non-elite athlete samples, and to determine the predictive roles of 
emotional intelligence components in athletes' stress coping strategies.

The main hypothesis was that performance in sports would moderate the relationship between the use of various stress coping strategies and the expression of emotional intelligence.

\section{Methods}

\section{Sample}

The total sample consisted of 340 athletes (217 men and 123 women). In terms of sports achievements, the subset of elite athletes comprised 171 athletes (109 men and 62 women), and the nonelite one 169 respondents (108 men and 61 women). Men's team sports taken into account were football, basketball, handball, volleyball and water polo, while individual sports were martial arts (judo), swimming and athletics. As for women, individual sports were the same, and the team sports being considered were some of those in which there were multiple rank contests in senior competition such as football, handball, volleyball. The criteria for including an athlete in the research sample were: training sessions at least five times a week and having a contract with a specific sports club. The greatest methodological challenge was to divide the sample into the elite and non-elite athletes. Athletes engaged in individual sports (both men and women) clustered into either elite or non-elite subsamples according to the criteria of winning or not winning a medal at a national championship for seniors and participating in international competitions. The criterion for joining the group of elite athletes of team sports was playing for the national team or for a club of the highest national rank that also competes in international competitions.

Before completing the questionnaire, the respondents were instructed that, while completing the stress coping questionnaire, they should think about the stressors they were confronted with in their sport.

\section{Materials}

Coping Inventory for Stressful Situations (CISS) (Endler \& Parker, 1990), or more specifically its adaptation, signed by Sorić and Proroković (2002) was used to evaluate the use of certain stress coping strategies. It consists of 48 items to which respondents respond on a five-point Likert-type scale. There are three subscales: task-oriented coping, emotionoriented coping, and avoidance, which has two of its own subscales, distraction and social diversion. The total score on the avoidance scale is obtained by summing the scores of the subscales.

Emotional intelligence was operationalized by the Emotional Competence Questionnaire (UEK45) (Takšić, 2002). It is a shortened version of the UEK-136 questionnaire and consists of 45 state- ments to which the respondent answers as by choosing one of the offered numbers on a fivepoint Likert-type scale. The answers represent the respondent's assessment of the development of their own abilities related to emotional competence. In addition to the total score, scores on the subscales ability to detect and understand emotions, ability to express and name emotions, and ability to manage and regulate emotions are also obtained.

\section{Data analysis}

Pearson's correlation coefficient, linear regression analysis to test the prognostic value of emotional intelligence in stress coping strategies, and hierarchical regression analysis were applied to test the moderating role of performance in the relationship between emotional intelligence and coping strategies.

\section{Results}

The results show the identical direction and significance of correlations between the taskoriented stress coping strategy, on the one hand, and all dimensions of emotional intelligence and the overall emotional intelligence score, on the other, in both elite and non-elite athletes (Table 1).

Significant correlations were obtained for the avoidance. In non-elite athletes, a correlation between all dimensions and an overall emotional intelligence score was obtained, whereas in elite athletes, no significant correlation between the dimension of perceiving and understanding emotions and avoidance was obtained.

The avoidance subscale distraction was significantly related to the dimensions of expressing and naming emotions, the management and regulation of emotions and to the total score of emotional intelligence in the sample of non-elite athletes only, whereas in the elite ones there were no significant correlations between emotional intelligence and distraction.

With social diversion in both samples of athletes, significant positive correlations were obtained with all dimensions and total emotional intelligence score.

The existence of a moderating effect involves determining the interaction effect of the moderator (sports performance, ie belonging to a group of elite or non-elite athletes) and predictors (emotional intelligence and its subscale) on the criterion variable (coping strategies - task, emotion, avoidance, distraction or social diversion oriented coping). For testing, it was necessary to construct a special interaction variable representing the product obtained by multiplying the predictor and moderator variables. Moderating multiple regression, which is a type of hierarchical regression analysis, is implemented by introducing new variables into the regression equation in each successive step. After each newly intro- 
Table 1. Corelations between coping strategies and emotional intelligence in elite and non-elite athletes

\begin{tabular}{|c|c|c|c|c|c|c|c|c|c|}
\hline \multirow[b]{2}{*}{$\begin{array}{l}\text { Coping } \\
\text { strategies }\end{array}$} & & \multicolumn{4}{|c|}{ Elite athletes } & \multicolumn{4}{|c|}{ Non-elite athletes } \\
\hline & & 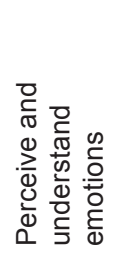 & 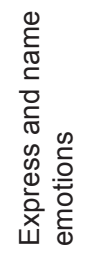 & 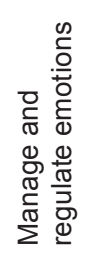 & 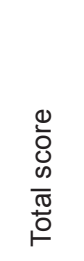 & 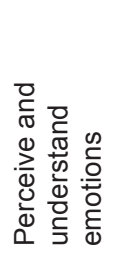 & 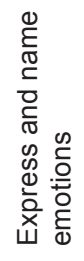 & 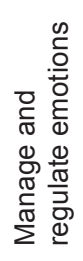 & $\begin{array}{l}0 \\
0 \\
0 \\
0 \\
0 \\
00 \\
0\end{array}$ \\
\hline \multirow{2}{*}{ Task-oriented } & $\mathrm{R}$ & .442 & .342 & .496 & .519 & .218 & .307 & .402 & .363 \\
\hline & Sig & .000 & .000 & .000 & .000 & .005 & .000 & .000 & .000 \\
\hline \multirow{2}{*}{$\begin{array}{l}\text { Emotion- } \\
\text { oriented }\end{array}$} & $\mathrm{R}$ & -.138 & -.051 & -.070 & -.103 & .138 & .173 & .104 & .170 \\
\hline & Sig & .078 & .523 & .377 & .198 & .079 & .028 & .186 & .034 \\
\hline \multirow{2}{*}{$\begin{array}{l}\text { Avoidance- } \\
\text { oriented }\end{array}$} & $\mathrm{R}$ & .127 & .264 & .227 & .241 & .205 & .356 & .386 & .387 \\
\hline & Sig & .103 & .001 & .004 & .002 & .009 & .000 & .000 & .000 \\
\hline \multirow{2}{*}{ Distraction } & $\mathrm{R}$ & -.026 & .111 & .042 & .041 & .106 & .293 & .306 & .277 \\
\hline & Sig & .738 & .155 & .592 & .600 & .178 & .000 & .000 & .000 \\
\hline \multirow{2}{*}{$\begin{array}{l}\text { Social } \\
\text { diversion }\end{array}$} & $\mathrm{R}$ & .299 & .356 & .391 & .413 & .275 & .328 & .377 & .399 \\
\hline & Sig & .000 & .000 & .000 & .000 & .000 & .000 & .000 & .000 \\
\hline
\end{tabular}

duced variable, the percentage of explained variance is determined. The significance of the contribution of the newly inserted variable is reflected in the change in the percentage of the explained variance of the criterion variable and expressed as $\mathrm{R}^{2}\left(\Delta \mathrm{R}^{2}\right)$. The significance of the change is tested by the $\mathrm{F}$ test. The last step of the analysis introduces a variable that results from the multiplication of the predictor and the assumed moderator. If there is a significant change in the percentage of explained variance, it can be concluded that the examined variable has a moderating effect on the relationship of predictors and criteria. To interpret a moderating effect it is necessary to present the result graphically. A statistically significant interaction is seen when the lines are not parallel. By testing moderating role of performance on the relationship between emotional intelligence and stress coping strategies, the following statistically significant results were obtained:

Emotional intelligence dimension - emotion management and regulation had a mean $(\beta=.269)$, statistically significant, independent contribution to the criterion variable of the avoidance stress coping strategy (Table 2). Athletes with higher scores on emotion management and regulation also had higher scores on avoidance-oriented stress coping strategy.

Performance was also an independent significant predictor and by introducing it into the regression equation, we significantly increased the percentage of the explained variance $(\Delta \mathrm{R} 2=.064)$. Non-elite athletes had higher scores on avoidance as a strategy for coping with stress.

Performance acts as a moderator in this relationship since, by introducing the interaction variable performance $\times$ emotion management and regulation into the equation, the amount of the explained variance showed statistically significant increase ( $\Delta \mathrm{R} 2=.010)$. The moderator effect is shown in Figure 1.

Performance in sport significantly moderated the correlation between the avoidance-oriented coping strategy and emotion management and regulation as an aspect of emotional intelligence. For both groups of athletes, the moving trend of both

Table 2. The moderating effect of athlete performance on the prediction of avoidance-oriented coping by the variable ability to manage and regulate emotions

\begin{tabular}{|c|c|c|c|c|c|c|c|c|}
\hline Model & Predictor & $\beta$ & $\mathrm{t}$ & $\mathrm{p}$ & $\mathrm{R}^{2}$ & $\Delta R^{2}$ & $F_{\left(\Delta R^{2}\right)}$ & $\mathrm{p}$ \\
\hline 1 & Manage and regulate emotions & .269 & 4.986 & .000 & .072 & .072 & 24.865 & .000 \\
\hline \multirow{2}{*}{2} & Manage and regulate emotions & .295 & 5.632 & .000 & \multirow{2}{*}{.136} & \multirow{2}{*}{.064} & \multirow{2}{*}{23.769} & \multirow{2}{*}{.000} \\
\hline & Performance (elit or non) & .255 & 4.875 & .000 & & & & \\
\hline \multirow{3}{*}{3} & Manage and regulate emotions & .412 & 5.203 & .000 & \multirow{3}{*}{.147} & \multirow{3}{*}{.010} & \multirow{3}{*}{3.871} & \multirow{3}{*}{.050} \\
\hline & Performance (elit or non) & .244 & 4.658 & .000 & & & & \\
\hline & $\begin{array}{l}\text { Performance } \times \text { Manage and regulate } \\
\text { emotions }\end{array}$ & .157 & 1.967 & .050 & & & & \\
\hline
\end{tabular}




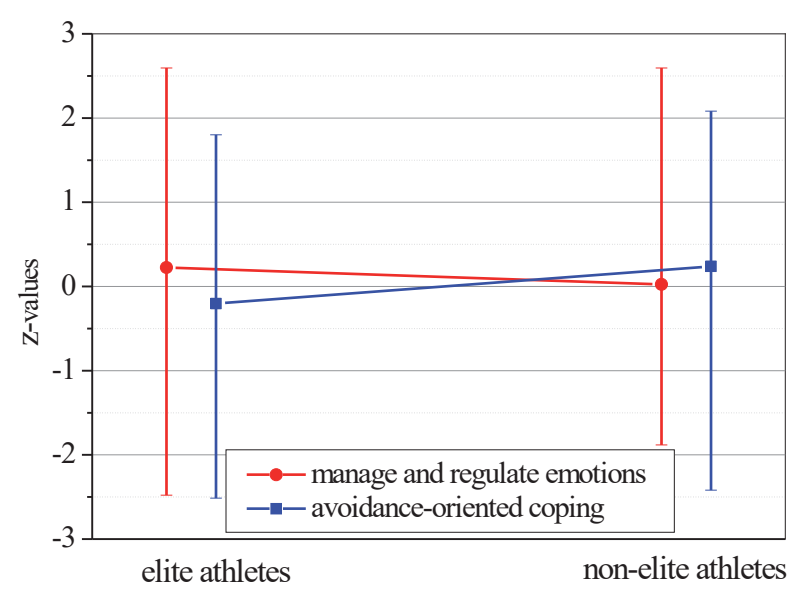

Figure 1. Performance as a moderator of the relationship between ability to manage and regulate emotions and avoidance-oriented coping

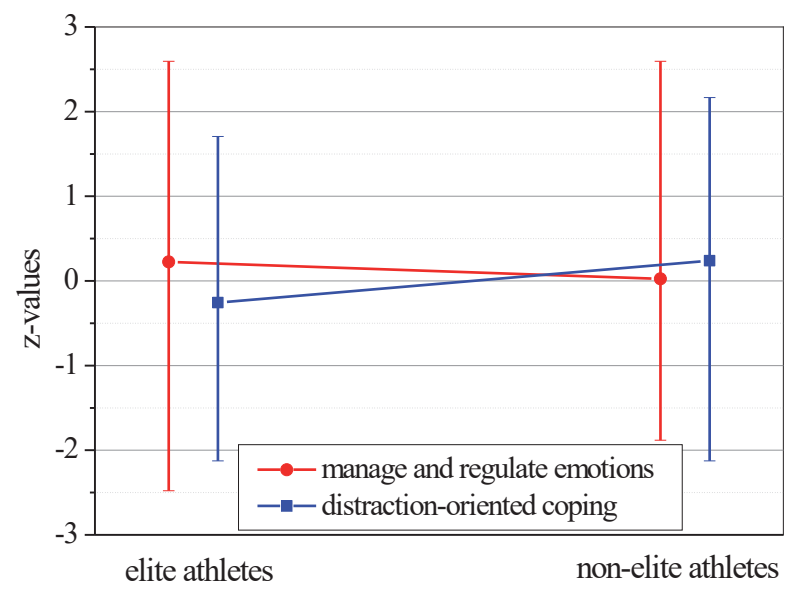

Figure 2. Performance as a moderator of the relationship between ability to manage and regulate emotions and distraction-oriented coping

Table 3. The moderating effect of athlete performance on the prediction of distraction-oriented coping by the variable ability to manage and regulate emotions

\begin{tabular}{|c|c|c|c|c|c|c|c|c|}
\hline Model & Predictor & $\beta$ & $\mathrm{t}$ & $\mathrm{p}$ & $\mathrm{R}^{2}$ & $\Delta R^{2}$ & $\mathrm{~F}_{\left(\Delta R^{2}\right)}^{2}$ & $\mathrm{p}$ \\
\hline 1 & Manage and regulate emotions & .137 & 2.496 & .013 & .019 & .019 & 6.228 & .013 \\
\hline \multirow{2}{*}{2} & Manage and regulate emotions & .165 & 3.093 & .002 & \multirow{2}{*}{.088} & \multirow{2}{*}{.070} & \multirow{2}{*}{24.780} & \multirow{2}{*}{.000} \\
\hline & Performance (elit or non) & .265 & 4.978 & .000 & & & & \\
\hline \multirow{3}{*}{3} & Manage and regulate emotions & .332 & 4.150 & .000 & \multirow{3}{*}{.110} & \multirow{3}{*}{.021} & \multirow{3}{*}{7.731} & \multirow{3}{*}{.006} \\
\hline & Performance (elit or non) & .248 & 4.678 & .000 & & & & \\
\hline & $\begin{array}{l}\text { Performance } \times \text { Manage and regulate } \\
\text { emotions }\end{array}$ & .224 & 2.781 & .006 & & & & \\
\hline
\end{tabular}

variables was the same, but in non-elite athletes correlation power was higher than in the elite ones.

The emotional intelligence dimension, emotion management and regulation, had a low $(\beta=.137)$, statistically significant, independent contribution to explaining variability in the distraction-oriented stress coping strategy as an aspect of coping (Table 3 ).

In this respect, performance in sport also proved to be an independent, statistically significant predictor of a low contribution whose introduction significantly increased the amount of the explained variance $(\Delta \mathrm{R} 2=.070)$. Non-elite athletes had higher scores regarding the distraction-oriented stress coping strategy.

The interaction variable performance $\times$ emotion management and regulation showed statistically significant increase of the explained variance of the criterion $(\Delta \mathrm{R} 2=.021)$, so it was concluded that sports performance was a moderator in this equation. The moderator effect is shown in Figure 2.

Performance in sport also moderated the correlation between the distraction-oriented stress coping strategy and emotion management and regulation. In elite athletes, the correlation power of these variables was very low (close to zero), while in non-elite athletes the correlation was significantly higher, and the variables varied in the same direction.

\section{Discussion and conclusions}

Considering the results of the correlation between emotional intelligence and its domains, on the one hand, and stress coping strategies, on the other, some relationships are clearly visible (Table 1). In the subsamples of elite and non-elite athletes, all domains of emotional intelligence individually and the total score showed statistically significant correlation with the task-oriented coping strategy and the use of social diversion. In the same subsamples, all domains of emotional intelligence individually and the total score showed no statistically significant correlation with the emotionoriented coping strategy. When it comes to the relationship between emotional intelligence and task-oriented strategy, the results are consistent with previous research (Jordan, et al., 2002; Por, et al., 2011; Salovey, et al., 2002). The authors of the studies mentioned above considered that the obtained correlation was the result of possessing emotional skills and knowledge as well as more efficient emotional regulation, hence, people with high emotional intelligence tended to use more active (task-oriented) strategies for coping with stress. Individuals who clearly experience and identify their emotions, who can direct their attention and resources toward coping and minimizing the impact 
of stressful events, can manage their emotions to change the stressful situation. Discussing emotionoriented coping strategy, these authors pointed out that emotions should not be avoided but should be used to cope with stress actively. Based on such discussions, it can be concluded that people with high emotional intelligence control emotions or, even better, use them adaptively when coping with stress, so there is, therefore, no need to regulate stressful situations through emotions, but through a specific action.

The next general correlation between emotional intelligence and stress coping strategies, which refers to the existence of statistically significant correlations between emotional intelligence and its domains with social diversion, as a coping strategy, can best be discussed given the essence of social diversion. At the core of coping with stress through a social diversion strategy is seeking social support that is not defined as a separate mechanism because it can lead to seeking entertainment and company (belonging then to avoidance strategies) or to seeking information about stressors and stressful situations (Parker \& Endler, 1992). Considering the possible impact of emotional intelligence on sports performance, some authors (Meyer \& Zizzi, 2007) maintain that emotional intelligence could have an effect on rational cognitive assessment, active coping, better management of emotions during stress, and a more appropriate use of social support. The results obtained in this study support this view of the emotional intelligence impact.

The distraction-oriented coping strategy is significantly related to the dimensions of the ability to express and name emotions and emotion management and regulation and to the total score of emotional intelligence only in the subsample of non-elite athletes, while elite athletes established no significant correlations between emotional competence and distraction. The findings obtained should be considered in the light of individual authors' claims (Gohm, et al., 2005; Matthews, et al., 2004) that the relationship between emotional intelligence and stress reduction through the use of adaptive strategies is not universal, that is, emotional intelligence can help reduce stress, but not to all people, due to the existence of different moderator variables, such as, for example, personality traits or circumstances.

The statistically significant, although low, correlations obtained between the avoidance strategy and certain aspects of emotional intelligence, can be explained by the fact that the scores on the social diversion scale as subscale of avoidance strategy are part of the overall score found in the avoidance dimension.
The existence of a statistically positive relationship between emotion management and regulation and social diversion in both subsamples, and the absence of significant correlations between emotion management and regulation and distraction in elite athletes, as opposed to non-elite athletes $(\mathrm{r}=0.306)$, created the expectation that the moderating effect of performance would be expressed primarily in the relationships between distraction and emotion management and regulation. Consequently, it was also expected that the possible moderating effect between emotion management and regulation and avoidance strategy would be due to the fact that the score on the avoidance dimension had been obtained by summing up the scores on its subscale of distraction and social diversion. Therefore, this section will discuss the moderating effect of performance on the correlation between emotion management and regulation and distraction. Distraction, as a subfactor of avoidance-oriented strategy, refers to directing at a new task unrelated to a stressful situation or event (Parker \& Endler 1992), while emotion management refers, to put it concisely, to the possibility of regulating emotions with the aim of improving a person's functionality (Mayer \& Salovey, 1997; Takšić, 1998, 2002). Less successful athletes use distraction-oriented coping more than successful one. Objective (or thus perceived) obstacles in non-elite athletes make it impossible for them to achieve better results. These obstacles can often be interpreted as stressors in relation to which it is impossible to do something to change them, and for many factors related to the physical manifestation of genetic predispositions, it is indeed very difficult or impossible. In such situations, less adaptive stress management strategies (emotion-oriented or avoidance) are resorted to. Given the research findings, we can assume that emotion management is a factor that, among others, causes non-elite athletes to turn to avoidant strategies, primarily distraction. Diverting attention, even for a short period of time, to things that are not related to the problem (especially if that stressor is connected with sports performance) probably cannot bring them success, due to constant and objective checks on their performance on the sports fields, but as Zotović (2004) rightly points out, overcoming does not have to be a completed or successful act.

The main limitation of this research refers, first of all, to the fact that stressors were not controlled, and therefore the influence that EI had on coping with specific stressful situations was not established. Future research should focus on communal coping since emotional intelligence can play a significant role in such social coping. 


\section{References}

Anshel, M. H., Sutarso, T., \& Jubenville, C. (2009). Racial and gender differences on sources of acute stress and coping style among competitive athletes. The journal of social psychology, 149(2), 159-178. doi.org/10.3200/ SOCP.149.2.159-178

Anshel, M.H., \& Kaissidis, A.N. (1997). Coping style and situational appraisals as predictors of coping strategies following stressful events in sport as a function of gender and skill level. British Journal of Psychology, 88, 263-276. doi.org/10.1111/j.2044-8295.1997.tb02634.x

Bagshaw, M. (2000). Emotional intelligence - training people to be affective so they can be effective. Industrial and Commercial Training, 32 (2), pp. 61 - 65. doi.org/10.1108/00197850010320699

Barlow, A., \& Banks, A. P. (2014). Using emotional intelligence in coaching high-performance athletes: a randomised controlled trial. Coaching: An International Journal of Theory, Research and Practice, 7(2), 132-139. doi.org/ 10.1080/17521882.2014.939679

Belem, I. C., Caruzzo, N. M., Nascimento Junior, J. R. A. D., Vieira, J. L. L., \& Vieira, L. F. (2014). Impact of coping strategies on resilience of elite beach volleyball athletes. Revista Brasileira de Cineantropometria \& Desempenho Humano, 16(4), 447-455.doi.org/10.5007/1980-0037.2014v16n4p447

Burton, D., \& Raedeke, T. D. (2008). Sport psychology for coaches. Human kinetics.

Calmeiro, L., Tenenbaum, G., \& Eccles, D. W. (2014). Managing pressure: patterns of appraisals and coping strategies of non-elite and elite athletes during competition. Journal of sports sciences, 32(19), 1813-1820.

Campo, M., Laborde, S., \& Mosley, E. (2016). Emotional intelligence training in team sports. Journal of Individual Differences 37, 152-158. 10.1027/1614-0001/a000201

Campo, M., Mellalieu, S., Ferrand, C., Martinent, G., \& Rosnet, E. (2012). Emotions in team contact sports: A systematic review. The Sport Psychologist, 26(1), 62-97. doi.org/10.1123/tsp.26.1.62

Cosh, S., \& Tully, P. J. (2015). Stressors, coping, and support mechanisms for student athletes combining elite sport and tertiary education: Implications for practice. The Sport Psychologist, 29(2), 120-133. doi.org/10.1123/ tsp.2014-0102

Cowden, R. G. (2016). Mental toughness, emotional intelligence, and coping effectiveness: An analysis of construct interrelatedness among high-performing adolescent male athletes. Perceptual and motor skills, 123(3), 737-753. doi.org/10.1177/0031512516666027

Crocker, P. R. E., Tamminen, K. A., \& Gaudreau, P. (2015). Coping in sport. In S. D. Mellalieu \& S. Hanton (Eds.), Contemporary advances in sport psychology: A review (p. 28-67). Routledge/Taylor \& Francis Group.

Crombie, D.,Lombard, C., \& Noakes, T. (2009). Emotional intelligence scores predict team sports performance in a National cricket competition. International Journal of Sports Science \& Coaching, 4, pp. 209-224. doi. org/10.1260/174795409788549544

Endler, N. S., \& Parker, J. D. (1990). Multidimensional assessment of coping: a critical evaluation. Journal of personality and social psychology, 58(5), pp. 844-854.

Endler, N. S., \& Parker, J. D. (1994). Assessment of multidimensional coping: Task, emotion, and avoidance strategies. Psychological assessment, 6(1), 50.

Fletcher, D., \& Sarkar, M. (2012). A grounded theory of psychological resilience in Olympic champions. Psychology of sport and exercise, 13(5), 669-678. doi.org/10.1016/j.psychsport.2012.04.007

Gaudreau, P., Nicholls, A., \& Levy, A. R. (2010). The ups and downs of coping and sport achievement: An episodic process analysis of within-person associations. Journal of Sport and Exercise Psychology, 32(3), 298-311. doi. org/10.1123/jsep.32.3.298

Gohm, C.L., Corser, G.C. \& Dalsky, D.J. (2005). Emotional intelligence under stress: Useful, unnecessary, or irrelevant? Personality and Individual Differences, 39, pp. 1017-1028. doi.org/10.1016/j.paid.2005.03.018

Gould, D., Finch, L. M., \& Jackson, S. A. (1993). Coping strategies used by national champion figure skaters. Research quarterly for exercise and sport, 64(4), pp. 453-468. doi.org/10.1080/02701367.1993.10607599

Jordan, P. J., Ashkanasy, N. M., \& Hartel, C. E. J. (2002). Emotional intelligence as a moderator of emotional and behavioral reactions to job insecurity. Academy of Management Review, 27, pp. 361-372. doi.org/10.5465/ amr.2002.7389905

Kavanagh, E., Brown, L., \& Jones, I. (2017). Elite Athletes' Experience of Coping With Emotional Abuse in the Coach-Athlete Relationship. Journal of Applied Sport Psychology, 29(4), 402-417. doi.org/10.1080/10413200 .2017.1298165

Kerdijk, C., Van Der Kamp, J., \& Polman, R. (2016). The influence of the social environment context in stress and coping in sport. Frontiers in psychology, 7, 875. doi.org/10.3389/fpsyg.2016.00875

Kim, M. S., \& Duda, J. L. (2003). The coping process: Cognitive appraisals of stress, coping strategies, and coping effectiveness. Sport Psychologist, 17(4), pp. 406-425. doi.org/10.1123/tsp.17.4.406

Kurimay, D., Pope-Rhodius, A., \& Kondric, M. (2017). The relationship between stress and coping in table tennis. Journal of human kinetics, 55(1), 75-81. doi.org/10.1515/hukin-2017-0007

Laborde, S., Brüll, A., Weber, J. \& Anders, L.S. (2011) Trait emotional intelligence in sports: A protective role against stress through heart rate variability? Personality and Individual Differences, 51(1), pp. 23-27. doi.org/10.1016/j. paid.2011.03.003 
Laborde, S., Dosseville, F., Guillén, F., \& Chávez, E. (2014). Validity of the trait emotional intelligence questionnaire in sports and its links with performance satisfaction. Psychology of Sport and Exercise, 15(5), 481-490. doi. org/10.1016/j.psychsport.2014.05.001

Laborde, S., Dosseville, F., \& Kinrade, N. P. (2014). Decision-specific reinvestment scale: an exploration of its construct validity, and association with stress and coping appraisals. Psychology of Sport and Exercise, 15(3), 238-246. doi.org/10.1016/j.psychsport.2014.01.004

Laborde, S., Guillén, F., \& Watson, M. (2017). Trait emotional intelligence questionnaire full-form and short-form versions: Links with sport participation frequency and duration and type of sport practiced. Personality and Individual Differences, 108, 5-9. doi.org/10.1016/j.paid.2016.11.061

Lane, A. M.; Thelwell, R. C. Lowther,J. \& Devonport, T. J. (2009). Emotional intelligence and psychological skills use among athletes, Social Behavior and Personality: an international journal, 37 (2), pp. 195-201. doi.org/10.2224/ sbp.2009.37.2.195

Lane. A. M. \& Wilson, M. (2011). Emotions and trait emotional intelligence among ultra-endurance runners, Journal of Science and Medicine in Sport, 14(4), pp. 358-362. doi.org/10.1016/j.jsams.2011.03.001

Lazarus, R. S., \& Folkman, S. (1984). Stress, appraisal, and coping. Springer Publishing Company.

Leprince, C., D’Arripe-Longueville, F., \& Doron, J. (2018). Coping in teams: exploring athletes' communal coping strategies to deal with shared stressors. Frontiers in psychology, 9, 1908. doi.org/10.3389/fpsyg.2018.01908

Lyons, R. F., Mickelson, K. D., Sullivan, M. J., \& Coyne, J. C. (1998). Coping as a communal process. Journal of Social and Personal Relationships, 15(5), 579-605. doi.org/10.1177/0265407598155001

Matthews, G., Zeidner, M., \& Roberts, R. D. (2004). Seven myths about emotional intelligence. Psychological Inquiry, 15, pp. 179-196.

Mayer, J. D., \& Salovey, P. (1997). What is emotional intelligence? In P. Salovey \& D. Sluyter (Eds.). Emotional development and emotional intelligence: Implications for educators (pp.3-31). New York, NY: Basic Books.

Mellalieu, S. D., Hanton, S., \& Fletcher, D. (2006). A competitive anxiety review: Recent directions in sport psychology research. In: S. Hanton and S. D. Mellalieu (Eds.) Literature reviews in sport psychology, 1-45. Nova Science Publishers, Inc.

Meyer, B. \& Zizzi, S. (2007) Emotional intelligence in sport: conceptual, methodological and applied issues, In: A.M. Lane (Ed) Mood and Human performance: conceptual, methodological and applied issues, pp. 131-152. , Nova Science Publishers, Inc. Pp.

Neely, K. C., McHugh, T. L. F., Dunn, J. G., \& Holt, N. L. (2017). Athletes and parents coping with deselection in competitive youth sport: A communal coping perspective. Psychology of Sport and Exercise, 30, 1-9. doi. org/10.1016/j.psychsport.2017.01.004

Nicholls, A. R. (2007). A longitudinal phenomenological analysis of coping effectiveness among Scottish international adolescent golfers. European Journal of Sport Science, 7(3), pp. 169-178. doi.org/10.1080/17461390701643034

Nicholls, A. R., Holt, N. L., Polman, R. C. \& Bloomfield, J. (2006). Stressors, Coping, and Coping Effectiveness Among Professional Rugby Union Players. Sport Psychologist, 20, pp. 314-329. doi.org/10.1123/tsp.20.3.314

Nicholls, A. R., Levy, A. R., \& Perry, J. L. (2015). Emotional maturity, dispositional coping, and coping effectiveness among adolescent athletes. Psychology of Sport and Exercise, 17, 32-39. doi.org/10.1016/j.psychsport.2014.11.004

Nicholls, A. R., \& Polman, R. C. (2007). Coping in sport: A systematic review. Journal of sports sciences, 25(1), 11-31. doi.org/10.1080/02640410600630654

Noblet, A. J., \& Gifford, S. M. (2002). The sources of stress experienced by professional Australian footballers. Journal of applied sport psychology, 14(1), pp. 1-13.

Parker, J. D., \& Endler, N. S. (1992). Coping with coping assessment: A critical review. European Journal of Personality, 6(5), pp. 321-344. doi.org/10.1002/per.2410060502

Perez, J.C., Petrides, K.V. \& Furnham, A. (2005). Measuring trait emotional intelligence, In: Schulze, R., \& Roberts, R. D. (Eds.). Emotional intelligence: An international handbook. (pp.181-202) Hogrefe Publishing.

Perlini, A. H., \& Halverson, T. R. (2006). Emotional intelligence in the National Hockey League. Canadian Journal of Behavioural Science, 38(2), pp. 109-119. doi.org/10.1037/cjbs2006001

Petrides, K. V. (2011). Ability and trait emotional intelligence. In T. Chamorro-Premuzic, S. von Stumm, \& A. Furnham (Eds.), The Wiley-Blackwell handbooks of personality and individual differences (p. 656-678). Wiley Blackwell.

Por, J., Barriball, L., Fitzpatrick, J. \& Roberts, J. (2011) Emotional intelligence: Its relationship to stress, coping, well-being and professional performance in nursing students, Nurse Education Today, 31, pp. 855-860. doi. org/10.1016/j.nedt.2010.12.023

Reeves, C. W., Nicholls, A. R., \& McKenna, J. (2009). Stressors and coping strategies among early and middle adolescent premier league academy soccer players: Differences according to age. Journal of Applied Sport Psychology, 21(1), pp. 31-48. doi.org/10.1080/10413200802443768

Sagar, S. S., Lavallee, D., \& Spray, C. M. (2009). Coping with the effects of fear of failure: A preliminary investigation of young elite athletes. Journal of Clinical Sport Psychology, 3(1), 73-98. doi.org/10.1123/jcsp.3.1.73

Salovey, P., \& Mayer, J.D. (1990). Emotional Intelligence. Imagination, Cognition and Personality, 9(3), pp. $185-211$. 
Salovey, P., Stroud, L.R., Woolery, A \& Epel, E.S. (2002). Percived emotional intelligence, stress reactivity and symptom reports: further explorations using the Trait Meta-mood Scale. Psychology and Health, 17(5), pp. 611-627. 10.1080/08870440290025812

Slaski, M. \& Cartwright, S. (2005). Emotional intelligence training and its implications for stress, health and performance, Stress and Health, 19, pp. 233-239. doi.org/10.1002/smi.979

Sorić, I. \& Proroković, A. (2002). Upitnik suočavanja sa stresnim situacijama Endlera i Parkera. [Endler and Parker Coping Stategies Questionnaire. In Croatian.] U K. Lackovic-Grgin \& Z. Penezic (Eds.), Zbirka psihologijskih mjernih instrumenata [Collection of Psychological Measurement Instruments]. Filozofski fakultet u Zadru, Hrvatska.

Szabo, A., \& Urbán, F. (2014). Do combat sports develop emotional intelligence? Kinesiology: International journal of fundamental and applied kinesiology, 46(1), 53-60.

Takšić, V. (1998). Validacija konstrukta emocionalne inteligencije. [Validation of the construct of emotional intelligence. In Croatian.] (Unpublished doctoral dissertation. University of Zagreb). Filozofski fakultet Sveučilišta u Zagrebu, Zagreb.

Takšic, V. (2002). Upitnici emocionalne kompetentnosti (inteligencije). [Questionnaires for emotional competence (intelligence) in Croatian] In K. Lackovic-Grgin \& Z. Penezic (Eds.), Zbirka psihologijskih mjernih instrumenata [Collection of Psychological Measurement Instruments]. Filozofski fakultet u Zadru, Hrvatska.

Tamminen, K. A., \& Gaudreau, P. (2014). Coping, social support, and emotion regulation in teams. In M.R. Beauchamp, M.A. Eys (Eds.), Group dynamics in exercise and sport psychology: Contemporary themes (2nd ed.), Routledge, New York, pp. 222-239.

Vaughan, R., Laborde, S., \& McConville, C. (2019). The effect of athletic expertise and trait emotional intelligence on decision-making. European journal of sport science, 19(2), 225-233. doi.org/10.1080/17461391.2018.1510037

Watson, M., \& Kleinert, J. (2019). The relationship between coaches' emotional intelligence and basic need satisfaction in athletes. Sports Coaching Review, 8(3), 224-242. doi.org/10.1080/21640629.2018.1491669

Zotović, M. (2004). Coping with stress: Basic conceptual and theoretical questions from the standpoint of the transactional theory. Psihologija, 37(1), pp. 5-32.

Submitted: April 22, 2020

Accepted: October 23, 2020

Published Online First: December 11, 2020

Correspondence to:

Nenad Stojiljković, Ph.D.

Department of Theoretical-Methodological Sciences

Faculty of Sport and Physical Education,

University of Niš, Serbia

Phone: +381 18 510-900

E-mail: snesadif@yahoo.com 